\title{
Water-Table Altitude in Kings and Queens Counties, New York, in March 1997
}

\section{Introduction}

Kings and Queens Counties, on western Long Island, N.Y. (fig. 1), obtain nearly all potable water from an extensive upstate reservoir system. The possibility that this source will be inadequate during future droughts, or during infrastructure repairs or other emergencies, has prompted consideration of using the underlying aquifer system as a supplemental source of water. In 1992, the U.S. Geological Survey, in cooperation with the New York City Department of Environmental Protection, began a long-term study of the aquifer system beneath Kings and Queens Counties to determine the feasibility of using ground water to supplement a possible shortfall in the city's reservoirwater-supply system. As part of this study, an observation-well network has been established to monitor water levels in the upper glacial, Magothy, and Lloyd aquifers. This fact sheet depicts the configuration of the water-table altitude in March 1997 as inferred from waterlevel measurements at selected observation wells.

\section{Hydrogeologic Setting}

The upper glacial aquifer is the uppermost hydrogeologic unit on Long Island; it consists of till deposits (clay, silt, sand, gravel, and boulders) along the north shore and outwash deposits (mostly sand, gravel, and clay) to the south. The outwash deposits are highly permeablehorizontal hydraulic conductivity is estimated to be 270 feet per day (Franke and Cohen, 1972); till deposits are typically less than half as permeable (Smolensky and others, 1989; Buxton and Shernoff, 1995).

The water table is within the upper glacial aquifer throughout most of Kings and Queens Counties. Thickness of the upper glacial aquifer in central Kings County is more than 200 feet (de Laguna, 1948), and in Queens County, it ranges from 0 to 300 feet (Soren, 1978; Buxton and Shernoff, 1995).

\section{Water-Level Measurements}

All observation wells represented in figure 1 are screened in the upper glacial aquifer. Water-level measurements were made by the wetted-steel-tape method and recorded to $1 / 100$ of a foot. The water-level monitoring network contains 59 observation wells, of which 26 are in Kings County, and 33 in Queens County. The average elevation of the screened zone in the wells in this network ranges from 9 to 19 feet below sea level.

\section{Water-Table Configuration}

The water-level contours show local mounds in the water-table with steep gradients in the northern part of Queens County, where low-permeability bedrock and the clay member of the Raritan Formation are near sea level (Soren. 1978; Buxton and Shernoff, 1995) and poorly permeable till deposits are present. Similar anomalously high water levels can be found on the peninsulas along the north shore of Nassau County to the east. The contours in the central and southern part of Kings and Queens Counties indicate a gentler gradient than in the northern part of Queens because the outwash deposits in these areas have higher hydraulic conductivity than the deposits to the north. Small depressions are likely to form in eastern Queens County as a result of public-supply pumping.

-By Jack Monti, Jr. and Anthony Chu

\section{References Cited}

Buxton, H.T., and Shernoff, P.K., 1995 , Ground-water resources of Kings and Queens Counties, Long Island, New York: U.S. Geological Survey Open-File Report 92-76, $111 \mathrm{p}$.

de Laguna, Wallace, 1948, Geologic correlation of logs of wells in Kings County, New York: New York State Water Power and Control Commission Bulletin GW-17, $35 \mathrm{p}$.

Franke, O.L., and Cohen, Philip, 1972, Regional rates of ground-water movement on Long Island, New York, in Geological Survey Research 1972: U.S. Geological Survey Professional Paper 800-C, p. C271 277

Smolensky, D.A.. Buxton, H.T., and Shernoff, P.K., 1989, Hydrologic framework of Long Island, New York: U.S. Geological Survey Hydrologic Investigations Atlas HA-709, 3 sheets, scale 1:250,000.

Soren, Julian, 1978, Subsurface geology and paleogeography of Queens County, Long Island, New York: U.S. Geological Survey Water Resources Investigation Open-File Report 77-34, $17 \mathrm{p}$

\section{For more information contact:}

Subdistrict Chief

U.S. Geological Survey

2045 Route 112, Bldg. 4

Coram, New York 11727
This fact sheet and related information can be found on the World Wide Web at: http://ny.usgs.gov

Additional earth science information can be obtained by accessing the USGS "Home Page" on the World Wide Web at: http://waterusgs.gov

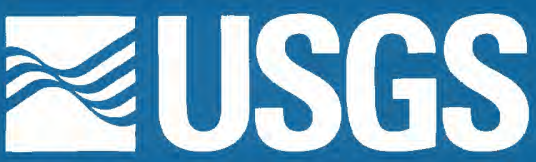

science for a changing world 


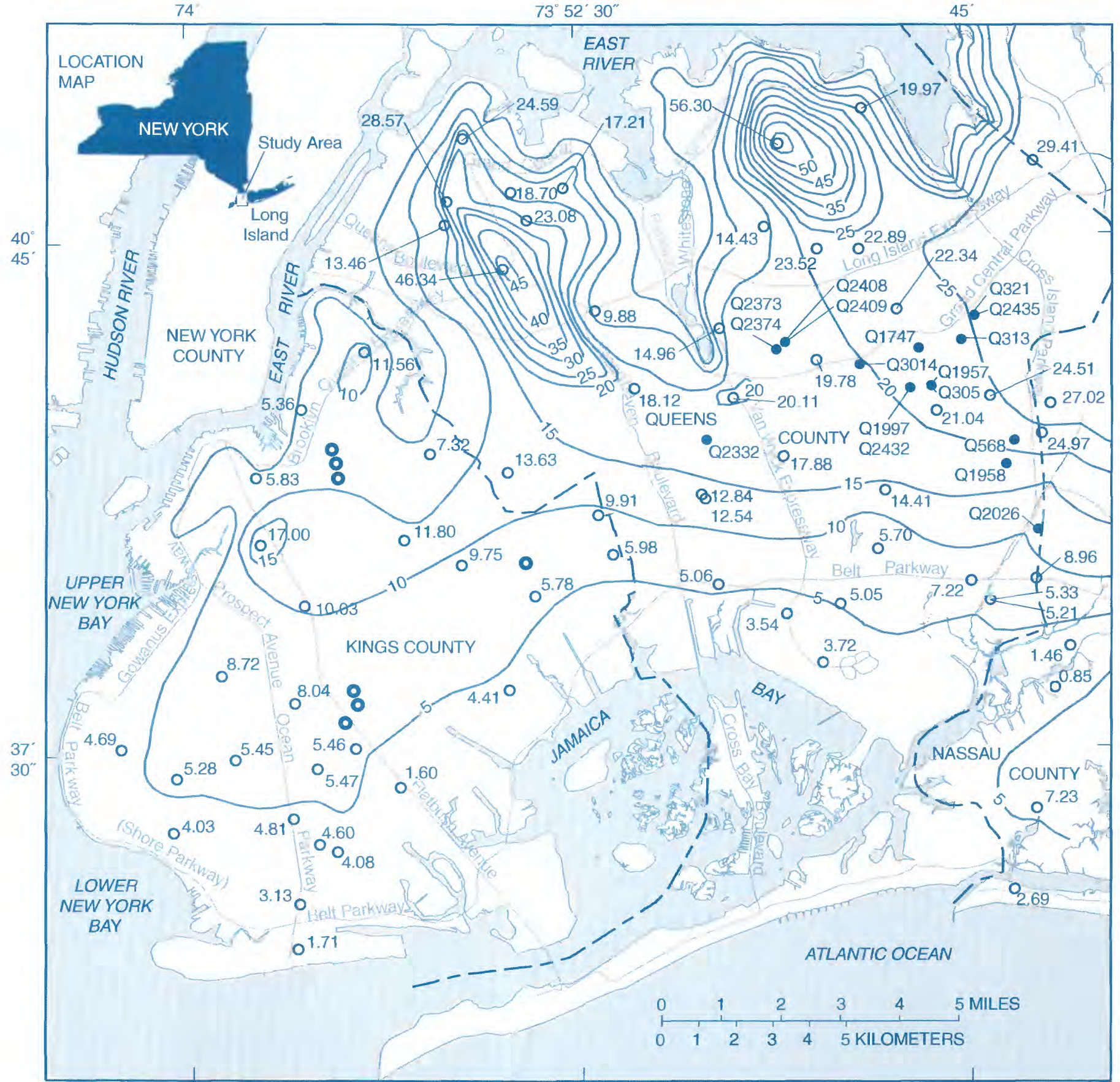

Base from New York State Department of Transportation, 1:24,000

\section{EXPLANATION}

\section{-5- WATER-TABLE CONTOUR-Shows altitude of water table. Contour interval 5 feet. Datum is sea level.}

Q2435 PUBLIC-SUPPLY WELL PUMPING IN MARCH 1997
- 22.76 OBSERVATION WELL- Number is water-level altitude, in feet above sea level.

- DEWATERING SITE-Metropolitan Transit Authority subway

Fig. 1. Water-table configuration of Kings and Queens Counties, Long Island, N.Y., in March 1997 